\title{
Ethnoreligious Urban Violence and Residential Mobility in Nigerian Cities: The Kaduna Experience
}

\author{
Samuel Danjuma Wapwera and Jiriko Kefas Gajere \\ Department of Urban \& Regional Planning, Faculty of Environmental Sciences, University of Jos, Jos, Nigeria \\ Correspondence should be addressed to Samuel Danjuma Wapwera; wapwera@gmail.com
}

Received 4 March 2016; Revised 8 August 2016; Accepted 30 January 2017; Published 6 March 2017

Academic Editor: Thomas Panagopoulos

Copyright (c) 2017 Samuel Danjuma Wapwera and Jiriko Kefas Gajere. This is an open access article distributed under the Creative Commons Attribution License, which permits unrestricted use, distribution, and reproduction in any medium, provided the original work is properly cited.

\begin{abstract}
This paper seeks to examine the ethnoreligious urban violence and residential mobility in the city of Kaduna with a view to make recommendations towards ameliorating its effects by evaluating the causal factors fueling the crisis and examining the pattern and direction of the residential mobility in the city. The sources of data were both primary and secondary. The sampling technique used was purposive and random sampling from two residential districts from both the northern and southern parts of the city. A total of 1,000 questionnaires were administered within the study areas and 900 questionnaires were collected. Face-to-face interviews were conducted with major stakeholders from the two parts. The data obtained were analysed using thematic and content analysis for the qualitative data whilst the quantitative data were analysed using simple percentages. The results revealed that the factors causing the ethnoreligious urban violence and residential mobility are unemployment, social institutional breakdown, politics, and colonial impact and the pattern/direction of the residential mobility in the city of Kaduna show a clear polarization along religious lines based reactive residential mobility between the two parts of the city. Based on these results recommendations were made to assist the academia, practitioners, and policy makers.
\end{abstract}

\section{Introduction}

Housing is, perhaps, the second most important basic human need after food and clothing. A house is not just a "shelter" (roof over one's head); it is something much more than protection from inclement weather and similar negative elements. Housing is better defined as a multifaceted bundle of services comprising all the needed facilities and services. The quest of most, if not all, citizens especially house owners is to transform a house into a home, which serves as both a private protection from the world that people want to lock out and a most convenient insulator from the world that people want to lock in. A housing unit, as a home, according to [1], projects its own status with respect to structure (the physical attributes of the dwelling itself and land it occupies); accessibility and utilities (the tangible services made available to the dwelling unit by the general community); rights (the community's legal norms applicable to the home owner); and the neighborhood, the surrounding houses and area.
Housing is considered as an important component of human settlement. Its conception, therefore, transcends the conservative view of four walls and a roof structure meant to protect man from the elements of weather $[1,2]$. According to Jinadu [2], housing is viewed as a bundle of services or a basket of goods which includes the physical structure itself, the ancillary facilities, and services within and around it, including the general environmental quality and amenities that surround the building. This view of housing as a composite whole recognizes that the occupancy of housing embraces the consumption of neighborhood services (parks, recreation, schools, hospitals, clinics, and etc.), a location (accessibility to employment and amenities and etc.), and the proximity to the social environment, that is, certain types of neighbors [3].

Housing is further considered to be the creation of a special (indeed total) environment in which people live and grow [4]. In line with this view, Igwe [5] posited that a home, that is, housing, represents an extended womb 
during the formative years of a child's physical, psychological, educational, and emotional development. In other words, housing (a house) is where children are brought up, the formative environment for the total development of a child. It equally serves as a human identity maker that determines the success of a man in life. It is an economic product, a commodity traded in the housing market, and a means of income generation. Housing is, thus, man's most valuable asset [6]. It is a social requirement and a nonnegotiable element of human settlements. The United Nations through its Article 25 (1) of the Universal Declaration of Human Rights has recognized housing as a basic right [6]. Similarly, the Habitat Agenda [7] contains provision on Human Right to Adequate Housing.

From the foregoing, one of the inferences we can make about housing, as an asset, a basic need and right, is that once built, it becomes relatively immobile, cannot be moved as a physical structure from one place to another. Any incidence that abruptly destroys the housing unit leads to sudden flight of a family and disrupts the family socially, economically, and psychologically.

A number of factors have been and are responsible for housing (a physical structure/product) or residential (dwelling unit) mobility in Nigerian cities. Kaduna, from available literature, is one of the few urban areas in Nigeria that has received academic attention on urban violence but none on, particularly, residential mobility. One of the recent studies on urban violence in the city in question by $\mathrm{Abdu}$ [8] was on the impact of ethnoreligious violence on youth culture.

The choice of Kaduna as a case study was informed due to the following: it is one of the regional headquarters during the colonial era (1914). However, the influence of the colonialists in the emergence of the city has made Kaduna, essentially, a colonial creation in terms of its current location, settlement pattern, and purpose. According to Urquhart ([9, p. 79], Kaduna was a special British colonial creation which was planned as Military and Administrative capital for the whole of Northern Nigeria. Lord Lugard chose the site and designed it specifically as capital city. Its special character epitomizes British colonial planned urban landscapes. ... Kaduna's more central position in Northern Nigeria helped it to become the site of the main Rail Junction in the north and has increased its importance as a center of growth for recent Nigerian development.

Kaduna city is located between latitude $10^{\circ} 20^{\prime} \mathrm{N}$ and $10^{\circ} 40^{\prime} \mathrm{N}$ and longitude $7^{\circ} 20^{\prime} \mathrm{E}$ and $7^{\circ} 28^{\prime} \mathrm{E}$. The city has a gentle undulating topography with no remarkable highlands. The most outstanding physical feature of the city is the Kaduna River. The River flows from a North-Easterly to the SouthWesterly direction and divides the city virtually into two parts. The Jos Plateau forms the source of the River which flows into the River Niger. The climate is tropical continental type with average daily temperature of about $25^{\circ} \mathrm{C}$. It has two distinct seasons: the dry season, experienced from November to April, and the rainy season, with annual rainfall between $1,100 \mathrm{~mm}$ and $1,200 \mathrm{~mm}$, occurring during the remaining months of the year. The initial Guinea Savannah type Vegetation has been impacted by urbanization and tends towards the Sudan Savannah type of Vegetation. The geology is the Basement Complex of Central Nigeria while the soils are generally ferruginous with loamy/silt along the Kaduna River.

For the purpose of this paper spatially it is limited to Kaduna city/metropolis. The residential districts studied comprised Sabon Tasha and Narayi in "Kaduna South" with Angwan Dosa/Badarawa and Rigasa in "Kaduna North." The issues scope focuses on changes of dwelling places, that is, residential mobility, occasioned by ethnoreligious crises (urban violence).

The theoretical underpinning for this paper is the theoretical framework that has direct relevance to political science theories with root causes of violence and theoretical and political perspective that looks at politics from the point of the dominated, the oppressed Sorel and, similarly, draws a distinction between the violence of the State, government, established political parties and the implicated trades unions and the violence of the proletariat [10].

It is against this background that this paper seeks to examine the ethnoreligious urban violence and residential mobility in the city of Kaduna with a view to make recommendations towards ameliorating its effects by evaluating the immediate causal factors fueling the crisis and examining the pattern and direction of the residential mobility in the city of Kaduna.

The study is justified based on the expected balanced mixed residential developments, ethnic heterogeneity, and religious interfaith coexistence (the hallmarks of a peaceful, safe and secured city) which would lead to the translation of Kaduna into a livable or sustainable city on the implementation of the recommended measures. On the other hand, residential, ethnic, and religious "enclavism" which can portend a time bomb for any city would be averted. The later situation seems to be the unfolding scenario into which urban violence, especially its ethnoreligious dimensions, appears to be compelling the city in question. No research on the effects of ethnoreligious urban conflicts on residential mobility across Kaduna city/metropolis is yet to be undertaken. This study is, therefore, apt and timely too in bridging the gap.

\section{Review of Relevant Literature}

There are several theoretical approaches to understanding of violence and underlying causal factors. However, the theoretical framework that has direct relevance to this work embraces political science theories of the root causes of violence; psychological theories; socioeconomic theories; and multicausal hypothesis. Based on these the causes and consequences of the ethnoreligious crisis and the patterns and direction of the residential mobility in the city of Kaduna would be considered.

\subsection{Factors of Urbanization and the Spatial Pattern of Residential Areas Distribution}

2.1.1. Population Growth. At independence in 1960, the population of Kaduna was put at 100,000. In 1991, the city's population leapt to almost 1,000,000 [11]. Projections show that the city's population stood at 1.08 million in 1996, more 
TABLE 1: Projected population of Kaduna metropolis from 1996 to 2020.

\begin{tabular}{lcc}
\hline SN & Year & Projected population \\
\hline 1 & 1996 & $1,080,671$ \\
2 & 2006 & $1,723,260$ \\
3 & 2014 & $2,229,332$ \\
4 & 2016 & $2,355,850$ \\
5 & 2020 & $2,608,886$ \\
\hline
\end{tabular}

Sources: $[12,13]$.

than doubled to 2.23 million in 2014 , and is expected to further rise to 2.61 million in 2020; see Table 1 .

The projections from Table 1 reveal that the population of Kaduna metropolis grew by about 62\% between 1996 and 2006 and about 77\% between 2006 and 2014. By all indications the city has witnessed phenomenal population growth. The 2014 projected population of Kaduna indicates that it constitutes about $28.26 \%$ of the total Kaduna State population of 7,886, 419. Rural urban migration alone is found to contribute by about $65 \%$ while the relocation of victims of crises and natural growth of Kaduna urban make up the remaining $35 \%$ of the population of the area [14].

In terms of ethnicity, the population of Kaduna metropolis is multiethnic. The ethnic composition of Kaduna South Local Government Area includes the Hausa, Yoruba, Igbo, Gbagyi, the original owners of Kaduna, the minority tribes of southern Zaria, the Atyap, Bajju, Jaba, Agworok, Shello, and so forth, and the other minority tribes of the country [15].

2.1.2. Consequences of Rapid Urbanization. In terms of spatial expansion, the total land use allocations at 1965 indicate that the city occupied an area of 16,800 acres [16]. Urban dynamics were attendant with the proliferation of satellite (urban) villages that include Rigasa, Gonin Gora, Narayi, and Sabon Tasha (Tsaunin Kura). The space engulfed by these and other districts/activity areas making up Kaduna metropolis is put at about $825 \mathrm{sq} . \mathrm{km}$. [14].

Major consequences of fast urban growth in Nigeria generally include unemployment, acute housing shortage, urban governance problems, urban services and facilities deficiencies, industrialization and environmental externalities, and poverty. Although figures for Kaduna are not available, unemployment constituted only between $5 \%$ and $20 \%$ of the urban labor force in Nigeria in 1971 with secondary school leavers as the main culprits [17]. By 1980s this figure jumped into millions and included the semiemployed people [18].

In subsequent years, graduates of Nigerian tertiary institutions and embracing the nonformally educated got caught up in the unemployment web $[19,20]$. Unemployment figures, according to level of educational attainment, indicate that nonformally educated unemployment rose from $12.2 \%$ in 1990 to $16.4 \%$ in 1994 . For the same period, statistics of unemployed secondary school leavers increased from $60.9 \%$ to $71.8 \%$ while postsecondary (tertiary graduate) unemployment rose from $4.0 \%$ to $4.7 \%$, in that order [21]. It has been estimated that over ten million school-going-age children are out of school in (the northern states of) Nigeria. Most of these children are products of Quranic schools "almajiris" and taken to street begging or hawking as a means of earning a living or being forced to do so by their teachers or guardians [22].

On poverty, reports show that from the 1980s to the mid-1990s, poverty incidence in the urban sector rose from $17.2 \%$ in 1980 to $58.2 \%$ in 1996 [23]. In the early 2000s, the World Development Report ranked Nigeria as the 179th poorest country on the globe [24]. The Report, together with other available literature, indicated that an estimated $70 \%$ Nigerians survive on less than USD1 or, at most, less than USD5 a day [24,25]. Despite the efforts made towards poverty reduction in the country in the past one decade through the MDGs programme, youth employment programmes (e.g., Subsidy Reinvestment Programme (SURE-P)), we believe urban poverty situation is still over $50 \%$.

The housing problem is a bundle comprising deficiencies in supply, housing markets accessibility, tenure, affordability, and financing. On the supply side, for instance, the past has been replete with ineffectual housing policies and actual provision. Between 1994 and 2000, for example, out of a projected national need of 8.2 million houses (3.2 million and 5 million for rural and urban dwellers, resp.) only one million housing units (about $12 \%$ ) were actually built [21, 26]. On affordability dimension, a peep into the housing affordability situation in some selected cities in Nigeria will suffice. Housing affordability is the ability and capacity of households to meet mortgage obligations without jeopardizing their health or reducing family nutrition intake [27]. For housing to be affordable to low income people, it must be tailored to some five factors, namely, total income level; housing characteristics; capacity to pay; employment needs and/or circumstances; and purchasing power and prices of the housing unit (i.e., production cost plus the profit margin of suppliers) which must be within the reach of low and medium income earners $[21,28,29]$.

In terms of urban management and governance, Kaduna lacks a city-wide elected government to affect these functions. The city comprises two complete local governments (Kaduna North and Kaduna South) and parts of two other local governments (Chikun and Igabi). The legal and constitutional instruments establishing these bodies, among other statutory agencies responsible for water, electricity and land matters, and so forth, do not allow for smooth, conflict-free, power tussle-free, and the needed cooperation among these bodies, on the one hand, and between them and the Kaduna State Urban Planning and Development Board (KASUPDA), on the other hand.

The provision of urban services and facilities is far below expectation. Solid wastes are managed by a contractual arrangement between the State Environmental Protection Agency (KEPA) and the local governments on the one hand and the private contractors, on the other hand. Some concerted efforts are being made in the collection and disposal as well as recycling initiatives, but the magnitude of solid waste generated is still overwhelming. Other environmental problems needing effective solutions include ambient noise, traffic congestion, pollution of all types, and urban flooding and erosion. 
TABLE 2: Incidences of some major ethnoreligious crises in other urban areas in Nigeria, outside the case study area.

\begin{tabular}{|c|c|c|}
\hline Year/urban area & Incidence of violence & Consequences/effects \\
\hline 1980, Kano & Maitatsine Islamic riots & 4,177 people dead; extensive destruction of property \\
\hline 1982, Kano & Muslim demonstrations & Churches burnt down \\
\hline 1982, Zaria & Religious disturbances & Destruction of mainly Christian property \\
\hline 1982, Maiduguri & Maitatsine-Kala kato Islamic sects clash & 118 people killed \\
\hline 1982, Yola & Maitatsine sect crisis & 584 people killed; wanton property destruction \\
\hline 1985, Gombe & Maitatsine sect uprising & 105 people dead; great damage to property \\
\hline 1986, Ilorin & $\begin{array}{l}\text { Muslim-Christian clash during Easter Christian } \\
\text { procession }\end{array}$ & Not available \\
\hline 1986, University of Ibadan & Muslim demonstration & $\begin{array}{c}\text { Figure of the Risen Christ-Chapel of Resurrection } \\
\text { burnt down }\end{array}$ \\
\hline 1991, Tafawa Balewa & $\begin{array}{c}\text { Religious "war" arising from a quarrel between a } \\
\text { Fulani and a Sayawa meat seller }\end{array}$ & $\begin{array}{c}\text { Several people dead; property worth millions of Naira } \\
\text { destroyed. }\end{array}$ \\
\hline 1991, Kano & $\begin{array}{l}\text { A bloody religious violence arising from a } \\
\text { procession by the Izala Islamic sect to foil Rev. } \\
\text { Reinherd Bonke (a German's) Christian crusade }\end{array}$ & $\begin{array}{c}\text { Thousands of lives lost; property valued at millions of } \\
\text { Naira destroyed }\end{array}$ \\
\hline 2001, Jos & An extensive Muslim-Christian rioting & $\begin{array}{l}\text { 2,000 lives lost; so many people displaced and } \\
\text { damage/destruction of major property }\end{array}$ \\
\hline 2010, Jos & Secret killings by fake soldiers & $\begin{array}{c}\text { Over } 300 \text { people dead; over } 800 \text { people wounded; over } \\
3,000 \text { people made refuges }\end{array}$ \\
\hline $\begin{array}{l}\text { 2010, Jos suburb (Zot, Dogo } \\
\text { Na Hauwa, and Rastat } \\
\text { villages) }\end{array}$ & Massacres by Fulani Nomads & 500 Christian Berom (ethnic) people massacred \\
\hline $\begin{array}{l}\text { 2011, Jos (North Local } \\
\text { Government Area) }\end{array}$ & Postelection riots & $\begin{array}{l}500-1,000 \text { people and } 4 \text { pastors killed; } 16 \text { churches } \\
\text { destroyed }\end{array}$ \\
\hline
\end{tabular}

Only 5\% of all new neighborhoods are planned on government layouts. A number of the urban villages or sprawls and squatter settlements (3\%) in the metropolis developed in the last fifteen years [30]. Forty-eight percent (48\%) of the residents in the metropolis lack or have inadequate or erratic supply of potable water; only $50 \%$ of the urban population and $20 \%$ of suburban population have access to potable water supply. $70 \%$ of the residents of Kaduna have access to electricity; yet $40 \%$ still rely on private power generators because of constant electricity power outages. Also, nearly $70 \%$ percent of the total population uses fire wood for cooking energy. About 13,549 kg (13.55 tons) of solid wastes is generated in the Kaduna metropolis on a daily basis [14]. Most of such waste is disposed in open dump sites, drainages, and streams without proper sorting, treatment, or recycling. Air pollution from combustion engines of automobiles (e.g., 10,000 motorcycles before they were banned in 2014) and gas flaring from Kaduna Refining and Petrol-Chemical Company, affect the environment and human health.

2.2. Ethnoreligious Crises in Urban Areas in Nigeria. In Nigeria as a whole, including the study area, Christianity and Islam are the two dominant religions. Outside the study area, ethnoreligious crises have taken place in other cities in Nigeria; see Table 2.

\section{Materials and Methods of the Study}

The data required for this paper are causal factors fueling the crisis and the pattern and direction of the residential mobility in the city of Kaduna and these data and information used in producing this paper were obtained from both primary and secondary sources.

The sampling technique used was purposively and randomly sampled from two residential districts each in the northern and southern parts of the city. Residents of the two selected residential districts in "Kaduna North" and the same number in "Kaduna South" constituted the subjects of the study. The crisis situation leading to inter- and intraresidential relocations made it extremely difficult to obtain any meaningful estimates of the total number of subjects for the study. The criterion for the selection of the survey residential districts was based on the observation of the apparently the most affected residential zones, North and South of the city. Those in the North were Hayi Banki (Kawo), Angwan Dosal/Badarawa, Tudun Wada, Kabala West/Nariya, and Rigasa. The residential districts in the South were Television, Gonin Gora, Sabon Tasha, Nasarawa, and Narayi. The selection was done through a simple random technique.

The medium of securing the secondary data was through a review of related literature (books, journals, and case studies) on urban violence with a particular focus on the ethnoreligious dimension. Primary data were obtained from the administration of predominantly structured questionnaire with few open-ended questions, field observation during some of the urban violence events in the study area, and faceto-face interviews with the traditional leaders of the selected residential districts.

The field survey using the structured questionnaire lasted for 90 days from 1st June, 2015 to 31st August, 2015, as Sixteen 
(16) Higher National Diploma students were employed to administer the questionnaires for effective administration of the said questionnaire and for these a five-day training workshop was organized for the field assistance which was carried out and supervised by the authors. The face-to-face interviews were conducted by the authors for the traditional leaders of the selected residential districts which lasted for 60 minutes per traditional leader over a period of six weeks (from 1st July, 2015 to 14th August, 2015).

The data obtained from the review of related literature, books, journals, and case studies amongst others, on urban violence with a particular focus on the ethnoreligious dimension and the face-to-face interviews were conducted by the authors for the traditional leaders of the selected residential districts and were analysed using thematic and content analysis. The quantitative data obtained from the questionnaire were analysed using simple percentages. The aim of these is to adequately link the empirical part of the paper to the theoretical framework.

\section{Results and Discussion}

One thousand $(1,000)$ questionnaires were purposively and randomly administered on the residents of "Kaduna North" (Angwan Dosa and Rigasa). Out of this number, 803 questionnaires were retrieved, giving a success rate of $80.3 \%$. In the case of "Kaduna South" (Narayi and Sabon Tasha), 845 questionnaires were retrieved out of the 900 administered; this yielded a success rate of $90.4 \%$. However, it is to be noted that in all cases respondents did not answer all the questions uniformly across board and hence the differences in the total number of respondents for each question.

The following are results obtained causes and consequences of ethnoreligious crises in Kaduna and the pattern and direction of residential mobility; change of residential accommodation since 1992, reasons for residential relocation, source and destination of the residential relocatees, size and type of former residential accommodation, size and type of new residential accommodation, and reasons for not moving/changing residential accommodation since 1992 amongst others.

\subsection{Causes and Consequences of Ethnoreligious Crises in} Kaduna. There are a number of causal factors to the violent events in Kaduna, the roots of some of which are traceable to the colonial days (remote) while others are recent (direct and indirect). The framework of the causal factors embraces impact of colonialism, breakdown of social institutions, "almajiranci" practice, and failed/failing government/state socioeconomic development efforts to meet the well-being/welfare needs of, especially, the youthful segment of the population which makes them easy prey to violenceprone activities. These may be considered the indirect/remote violence-inducing factors. Colonialism is blamed for having laid some of the roots of the spate of violent conflicts plaguing the city currently. Kaduna was a colonial creation with migrants moving into Kaduna; most area were settled in areas that were assigned on the basis of ethnicity, class, and religion in the colonial spatial organization, in line with the colonial segregation policy, which is believed to be shaping the contemporary character of ethnoreligious violence in Kaduna [8]. In this light, it has been asserted that colonization, at the outset, "is violence in its natural state, and will only yield when confronted with greater violence" [32]. Colonization and structured careless brutality are seen as breeding resentment and the libidinous development of violence, a reactive violence that is rejected by the elite and political parties; yet it further fuels alienation and organized popular violence against them and the brutality of the colonial regime which they seem to have inherited or perpetuating. Based on the concept of geographical scale as a structuring principle, this scenario is a snap shot of how the Kaduna city space/places were constituted and are being contested from the concerned actors' perspective of the violence.

There is also violence that occurs due to social institutional breakdown. When child-bearing, child upbringing, and child nurturing practices in families and social/youth institutions are poor there is a high tendency of breakdown. Failure of government/state to provide for the economic well-being of (the young elements of) the citizenry in terms of employment opportunities, infrastructure, and services to meet their basic needs can generate violent tendencies in people [12]. The "almajiranci" Muslim education system which permits a pupil from an early age to leave his family to live and learn under a teacher (58) and has to beg for his food and other basic needs makes them prone to the manipulative tactics of politicians that push them unsuspectingly to violent events.

In Kaduna, the table below provides some of the major ethnoreligious violent experiences stating the direct or immediate causes that have engulfed the urban area leading to casualties and destruction of property. Here, ethnicity and religion are the more direct/immediate causal factors.

From the table, it is clear that religious riots/conflicts have resulted in the untimely death of several thousands of people and tens of thousands displaced, and numerous property including housing units worth billions of naira were either destroyed or damaged in Kaduna metropolis. At least, hundreds of churches and mosques, hotels and cinema businesses as well as vehicles, private homes, and so forth have been destroyed in major riots [33]. These are the tangible impacts. The intangible effects, which cannot be quantified, include loss of family bread winners and particularly the youth members of the families; in many cases too women and children were caught up in the inhuman man-slaughter and family disorganization/destabilization, among other psychotraumatic effects that will linger for long in memories of, especially, the affected members of the city inhabitants. The effects of the violent conflicts have their theoretical implications. Since most, if not all, the violent incidences were unsuspected/unexpected, sudden, taking the victims unawares, the immediate reaction of those who survived was to flee for safety straight from their working places or businesses establishments to any nearest law enforcement office or establishments, police/army barracks (at least temporarily); the displacements were certainly forced and involuntary.

Moreover, violent religious riots have created an atmosphere of insecurity, uncertainty, suspicion, and lack of trust 
TABLE 3: Some of the major religious riots and conflicts in Kaduna.

\begin{tabular}{|c|c|c|}
\hline Date & Description (cause) & Consequences \\
\hline 1987 & $\begin{array}{c}\text { Retaliatory Muslim religious riots that extended to } \\
\text { Katsina, Funtua, Zaria, and Gusau following } \\
\text { Muslim-Christian riots at Kafanchan College of } \\
\text { Education. }\end{array}$ & $\begin{array}{l}\text { Numerous church buildings burnt down; Christian } \\
\text { property damaged; many lives lost }\end{array}$ \\
\hline 1987 & $\begin{array}{c}\text { Queen Amina College Students' religious clash over } \\
\text { female Muslim students' demand to wear Islamic } \\
\text { uniform }\end{array}$ & Christian students and staff attacked. \\
\hline 1988 & $\begin{array}{c}\text { Religious riots, ostensibly among Kaduna Polytechnic } \\
\text { Students }\end{array}$ & Destroyed the foundation wall of the Christian chapel \\
\hline 1992 & $\begin{array}{l}\text { A communal feud between the Katafs and Hausas that } \\
\text { ultimately took the dimension of inter-religion war } \\
\text { (Muslim versus Christian) in the major cities of Kaduna } \\
\text { State (including Kaduna city) }\end{array}$ & Several lives were lost and property destroyed \\
\hline 2000 & Muslim-Christian conflict over Sharia law & $\begin{array}{l}2,000-5,000 \text { people were killed; ethnic cleansing; } \\
\text { extensive property damage }\end{array}$ \\
\hline 2002 & $\begin{array}{l}\text { Miss World riots including Abuja; Muslim-Christian } \\
\text { clash after newspaper article. }\end{array}$ & $\begin{array}{c}250 \text { people were killed; } \\
\text { 20,000-30,000 people displaced; widespread property } \\
\text { damage }\end{array}$ \\
\hline $\begin{array}{l}\text { From, especially, early } \\
\text { 2010's }\end{array}$ & $\begin{array}{l}\text { "Boko Haram" (antiwestern education) } \\
\text { insurgency/terrorist group activities }\end{array}$ & $\begin{array}{l}\text { Bombings, suicide bombings, killings using guns; } \\
\text { adoption of people; several thousands of people were } \\
\text { killed; mosques and, at least, } 750 \text { churches burnt down } \\
\text { in northern Nigeria }\end{array}$ \\
\hline
\end{tabular}

Sources: [33-35].

between the practitioners of the two major faiths in Kaduna. This has further engendered religious group, conflicts which can be conceptualized as a specific form of conflict between groups which differ ideologically along religious lines within a pluralistic setting. Religion is characterized by sharp subdivisions of the society specifically with clear-cut dichotomies exemplified in the "good" and the "lost," "sacred" and "profane," or "brethren" versus "the rest of the world" who are expected to share in the life after $[33,36]$. The "we" feeling among members propels the fencing out of nonbelievers who are technically condemned to hell unless they repent. The politicization of religion lies as the root cause of this religious violence. Religious intolerance (hostility towards other religions as well as inability of religious adherents to harmonize between theories and the practical aspect of religion) has been identified as one of the major sources of religious conflicts in all societies [37]. Yet another source of religious conflict is indoctrination, which yields religious fanaticism.

The role "ethnicity" plays in violence in the study area is and/or may be attributable to the inclination of certain ethnic groups towards the adoption of either Islam or Christianity. This is to say certain ethnic groups have become associated with a particular religion. The population of Kaduna metropolis is multiethnic. The inhabitants of Kaduna who are of the Hausa/Fulani and Kanuri ethnic extractions overwhelmingly practice the Islamic faith (are Muslims) and have their highest concentrations in "Kaduna North." The vast majority of the other ethnic groups, the Yoruba, Igbo, and Gbagyi (the original indigenes of Kaduna), the minority tribes of southern Zaria, the Atyap/Katafs, Bajju,
Jaba, Agworok/Kagoro, and Shello, and the other minority tribes of the country [15] are Christians with their highest concentrations in "Kaduna South." The communal feud between the Katafs and Hausas that finally turned into an interreligious war in the main cities of Kaduna State including Kaduna (Table 3) is illustrative. Even the Miss World event that was yet to take place took a religious coloration and degenerated into a Muslim-Christian clash after a newspaper article and this affected the study area. Feuds between one ethnic community and another degenerate into religious riots in which even "ethnic cleansing" is mentioned.

The ethnoreligious violence has together created "Makka" (Mecca) and "Jerusalem" in Kaduna city; that is, the city is "divided" into two parts that are dominated by Muslims and Christians, respectively. This is the crux of the study. The River Kaduna forms the dividing line. While most of the Muslims live in the northern part of the metropolis, most of the Christians live in the southern part. Most of the Christians who lived and owned or rented houses and whose houses were destroyed in residential districts in the northern part of the city sold them and relocated to the southern part. Likewise, Muslims who lived, owned, or rented houses and whose houses were destroyed in the southern segment of the metropolis sold their houses and relocated to the northern part [26]. This phenomenon is what is referred to as "residential mobility" in this study. The daily experiences just cited above outline the experiences of a cross section of the residents from the northern part and southern part, before and after the crisis. A Christian who said she was born in Kawo in "Kaduna North" and lived there for over 23 years said she had to relocate to Gonin Gora, "Kaduna South" in 2002, 
because she was attacked by members of the neighborhood in the course of which she lost an uncle and friends and her house was destroyed including other property and cars. Alhaji Tajudeen Ajibade (a journalist) is reported to have said he lived in Gonin Gora, "Kaduna South," for over 12 years but all that he labored for were destroyed. He confessed that nobody hated him, but he was not spared as a result of the 2000 crisis. Another Muslim revealed that he grew up in Tudun Wada, where in those days they lived together with Christians in the same compound and on the same street in peace. Most of his childhood friends were Christians. However, according to him, everything had now changed since the Sharia crisis of 2000, after which (most) Christians in Tudun Wada and Ungwar Sanusi left to Sabon Tasha and other Christian-dominated areas in "Kaduna South." Yero, a former governor of Kaduna State, acknowledged and lamented this polarization of Kaduna along Muslim- Christian divide [38].

This polarization of Kaduna along Muslim-Christian divide, and from observations over the years, seems to imply that the ghost of violence on the basis of ethnicity and religion still hangs over the city. Any definitive conclusions from the facts presented on the causes and the effects of the ethnoreligious violence in the study area that suggest that the essence of interreligious violent events has changed over time would have to be cautiously made. This is because violence can be used and abandoned [32] and used again, and only time will tell. The introduction of the "Boko Haram" phase of the violence still has elements of extreme religious fanaticism connotations since the sect believe they are fighting a religious war and sometimes wrongly associate "western education" with Christianity. On our part, we believe the solutions the paper presents, if implemented to the letter, will provide the leeway.

4.2. Pattern and Direction of Residential Mobility. "Pattern" of residential mobility, as used here, refers to the shape and design of the reactive relocations whether Muslims concentrated in Muslim-dominated zones and Christians clustered in Christian-dominated districts and whether there were intraresidential relocations within each of the ethnically/religiously dominated zones. "Direction" of residential mobility, on the other hand, relates to source and destination of those who relocated, particularly the cardinal direction of the relocations, that is, whether they were from either "Kaduna North" or "Kaduna South" and vice versa. The "North-South," "South -North" residential mobility across the "religious/ethnic divide" is our main concern. These are elaborated, particularly, under the subheading "Source and Destination of those who relocated.

4.2.1. Change of Residential Accommodation Since 1992. On the question of whether they had any cause to change their places of abode in the last 12 years or so, $39.12 \%$ of the respondents in "Kaduna North" said "Yes" while $60.88 \%$ said "No." On the frequency of change of dwellings, the analysis of the affected respondents' responses showed that respondents who relocated their residential accommodation once or twice were in the preponderance constituting $93.42 \%$ of the total respondents in question. Those who relocated their residences three to four times represented just 6.58\%. In response to the same question and period in "Kaduna South" $54.68 \%$ of the respondents indicated "Yes"; the remaining respondents $45.32 \%$ said "No." Responses on the frequency of change of dwellings by the respondents concerned showed that those who relocated their places of abode once or two times were in the preponderance; that is representing $91.91 \%$. Those respondents who had changed their dwellings four or five times or more formed only $2.98 \%$ of the total respondents here. The broad picture portrayed by the situation in the two zones of the study area is that over $50 \%$ and almost $40 \%$ of the respondents, respectively, had reason to change their dwelling places once or twice within the period in question. The pattern of residential relocation is characterized by Muslims congregating in Muslim-dominated residential districts and Christians clustering in Christian-dominant residential zones.

4.2.2. Reasons for Residential Relocation. On this, some fourteen (14) possible reasons were listed for the respondents to indicate as appropriate. The outcome of the analysis for "Kaduna North" revealed that "troublesome neighbors" and "ethnic and religious crises," together with crises-induced desire to live among members of the same ethnic and religious groupings, constituted more than half (175 out of 328 , that is, $53.36 \%$ ) of the respondents' push factors for their residential relocation. On the same fourteen (14) possible reasons, the outcome of the analysis on the responses in "Kaduna South" revealed that the same ethnoreligious related responses ("troublesome neighbors," "ethnic," and "religious" crises together with the desire "to live among ethnic members" and "people of same religion") constituted 55.11\% (or 377 out of 684 respondents) of the factors responsible for respondents' residential mobility.

4.2.3. Source and Destination of the Residential Relocatees. The analysis on this was done on the basis of whether the movement was from Muslim-dominated to Christian-dominated residential areas and vice versa; from Muslim-dominated to Muslim-dominated areas; Christiandominated to Christian-dominated areas (i.e., concentrated or clustered, which refers to "pattern" of residential mobility). The outcome of the analysis on this factor showed that the number of respondents caught up in the residential mobility from Christian- dominated "Kaduna South" to Muslimdominated "Kaduna North" numbered 116, that is, $69 \%$ of the total movements, while intraresidential mobility within the Muslim-dominated "Kaduna North" constituted 31\% of the movements. This situation may be attributable to either intersectarian feuds among the Islamic faithful or other nonethnoreligious factors. For "Kaduna South," with respect to the pattern and direction of residential mobility, the result of the analysis on the responses on this constituted $65.63 \%$ of the total movements. The combined intraresidential mobility within Christian-dominated "Kaduna South" made up the remaining $34.37 \%$. The intraresidential mobility constitutes part of the direction of the residential relocations. The conclusion is that ethnoreligious violence occasioned massive 
North-South, South-North (direction) reactive residential mobility between "Makka" and "Jerusalem" in Kaduna metropolis.

4.2.4. Size and Type of Former and New Residential Accommodation. The outcome of the analysis of the respondents' responses on these variables revealed that respondents who occupied rooming accommodation prior to the ethnoreligious crises in "Kaduna North" were the largest subcategory representing $72.36 \%$ of the total whereas those who lived in 2 bedroom housing units and above made up a mere $16.8 \%$.

The result of the analysis on the same variables for "Kaduna South" showed that respondents who lived in rooming (1-3 rooms) dwellings during the preethnic and religious crises period were the largest, representing $81.69 \%$ of the total, whereas those who occupied 1 bedroom to 3 bedrooms and above made up just $18.31 \%$ of total.

Consequently, when considering the size and type of new residential accommodation the result of the analysis revealed that $50.71 \%$ of the respondents lived in rooming residential accommodation in "Kaduna North," while $30.19 \%$ occupied 2 bedroom and bigger housing units' category. Respondents who were (temporarily) accommodated by relatives or friends made up $9.13 \%$. The result of the analysis on the same issues in "Kaduna South" showed that $61.21 \%$ of the respondents occupied rooming (1-3 rooms) dwellings in their new destination and $38.79 \%$ lived in 1 bedroom to 4 bedrooms and above residences. Almost $5 \%$ of the respondents, who could not secure accommodation, had to put up with relatives, friends, and so on. Respondents who occupied 1-3 rooming accommodation in their new destinations in both Kaduna "North" and "South" made up more than half of the total subjects involved in residential mobility.

4.2.5. Reasons for Not Moving/Changing Residential Accommodation Since 1992. The outcomes of the analyses on ethnoreligious related factors responsible for residential relocations have already revealed that not all the respondents were involved. The outcome of the analysis on the responses showed that respondents that indicated "owner-occupier", "friendly neighbors," "living with same ethnic members," and "religious crises" constituted the lion share representing $71.82 \%$ of the total respondents in "Kaduna South." In "Kaduna North," $70.46 \%$ of the respondents indicated they had not changed their places of abode throughout the study period. The reasons they gave for not moving were "selfownership of house occupied" (not destroyed by ethnic or religious violence), "cordial/friendly neighbors," "same religion with neighbors," and "living with ethnic members." This implies that, in the absence of ethnoreligious crises, nearly three-quarters of the respondents would have not desired to change their places of abode.

\section{Conclusions and Recommendation}

The paper has established that several ethnoreligious crises ravaged Kaduna city for many years. Ethnoreligious related factors which compelled the residential mobility constituted smaller percentage and a greater percentage of the overall reasons for causing relocation in "Kaduna North" and "Kaduna South," respectively.

While some of the victims from "Makka" relocated from "Jerusalem," more than double that number from "Jerusalem" relocated from "Makka." The case is greater for the victims in "Kaduna North" and little below those in "Kaduna South" because they have to support relatives and friends as an interim solution.

The patterns of change in residential accommodation are along Christian and Muslim inclination and mobility is from either the Muslim-dominated to Christiandominated residential areas or from Muslim-dominated to Muslim-dominated areas; Christian-dominated to Christiandominated areas. The reasons for residential mobility are as follows: "troublesome neighbors" and "ethnic" and "religious" crises together with the desire "to live among ethnic members" and "people of same religion."

This study, the first of its kind in the study area, has unraveled the deep rooted causes and revealed the actual and latent cankerous effects of the ethnoreligious crisis driven residential mobility on the civilized way of living and the proper functioning of the city in view. This will serve as a "wake-up" call on both the city policy makers, city planners and managers, and the generality of the residents to all work in concert and as a matter of urgent attention to evolve people-oriented urban policies, city plans, and development programmes, as well as imbibe right attitudinal changes. These would facilitate the nibbling of emerging ugly monster in the bud and restore Kaduna to its initial all-inclusive and unified city where residential mix and ethnoreligious heterogeneity were its spice of life and functioning. Based on the foregoing, put together, there is the need to take urgent steps to turn the situation around.

Kaduna city from its inception has been a plural or heterogeneous community, ethnically and religious-wise. Its "polarisation" into "Makka" and "Jerusalem" portends danger for its security, sustainability, and prosperity. All the stakeholders have vital roles to play if the future of Kaduna is to be secured and sustainable.

Fortunately, some of the basic institutions, bodies, agencies, departments, outfits, and so forth that could be used to turn the situation around are in place. The constitution is available and being amended as appropriate. The defense, the police, and civil defense and other law enforcement establishments and the traditional institutions are in place. The civil society watches dogs, and community based (vigilante) organizations are available. The federal, state, and local government has the people's mandate to formulate the policies and set and enforce the rules to regulate the activities of all these setups and outfits in the country and/or at the appropriate tiers of government where these are not yet on ground.

Effective city planning and management of Kaduna will be an indispensable, positive solution strategy. The initial segregation mentality fused in the minds of the inhabitants of Kaduna by the violence builtin nature of the colonial spatial organization of the city can be diffused by concerted 
citizen education on the importance of peace and peaceful coexistence, consulting, involving them in all city planning activities to allow them to express their views, and incorporating the same in the city planning efforts.

Based on the results obtained the recommendations were made; for example, the Max Lock and Partners (1967) Kaduna Master Plan has been bastardized, not consistently implemented, and has become moribund and irrelevant in the face of unprecedented rapid city growth and expansion. A thorough revision of the master plan and adoption of a more efficacious approach, such as Strategic/Structure Planning, may be a wise starting step towards a secured, sustainable, prosperous, and livable Kaduna city. City planning is needful here because planned urban growth, urban productivity, and violence have been found to be related. While the correlation between planned urban growth and urban productivity is positive, that between urban productivity and violence is negative [39]. Urban planning plays a vital role in minimizing poverty which is a potent root of urban violence. Urban planning is a social or welfare service and an economic development strategy for mitigating the economic disparity between the low/poor and upper socioeconomic classes through its efficient spatial distribution of development opportunities and facilities that include employment, housing, social infrastructure and public utilities, transportation facilities, and recreation facilities to enable all socioeconomic classes to achieve both human and material improvements. Compatible, mixed land uses bring together the low, medium, and high income classes together and facilitate social mix and sharing of facilities and services. Mixed residential neighborhood planning with the required neighborhood facilities and services (including religious) and small and medium enterprises is an urban planning/design strategy that is poised to promote equal access to, sharing, social interaction and reduction of inequality. Urban planning and design promote and/or enhance city security through its provision for CCTV, street addressing techniques, street lighting, building height, and setback standards.

Further research is recommended on the possible occurrence of morbidity and other qualitative effects of reactive residential relocation, issues of personal adjustment of individuals/families in their new environments, or an ecological perspective that takes into account both the subjective and objective features of the old and new environments. This will go a long way in complementing this treatise.

\section{Competing Interests}

The authors declare that they have no competing interests.

\section{References}

[1] T. Agbola, L. Egunjobi, and C. O. Olatubara, Eds., Housing Development and Management: Book of Readings, Department of Urban and Regional Planing, University of Ibadan, Ibadan, Nigeria, 2007.

[2] A. M. Jinadu, Understanding the Basics of Housing in Nigeria, King James Publishers, Minna, Nigeria, 2004.
[3] T. Agbola and M. Alabi, "The research process", in Contemporary Social Science Research Methods: A Practical Guide, T. Agbola, L. Egunjobi, C. Olatubara, D. O. Yusuf, and M. Alabi, Eds., MURLAB Searchlightwisdom Educational Services Publishers, Ibadan, Nigeria, 2000.

[4] E. K. Clois and C. K. Joan, Residential Housing, The Goodheart Willcox Company Inc, South Holland, Ill, USA, 1996.

[5] J. Igwe, "The urban poor: some aspects of the residential circumstances," in The Urban Poor in Nigeria, P. K. Makinwa and A. O. Ozo, Eds., Evans, Lagos, Nigeria, 1987.

[6] UNCHS, An Urbanizing World: Global Report on Human Settlements, HABITAT, 1996.

[7] Urban Indicators Guidelines, "Better Information, Better Cities," Monitoring the Habitat Agenda and the Millennium Development Goals- Slums Target.

[8] H. Abdu, Urban Dynamics, Ethno-Religious Crises and Youth Violence in Kaduna, Department of Political Science and Defence Studies, Nigerian Defence Academy, Kaduna, Nigeria, 2003.

[9] A. W. Urquhart, Planned Landscapes of Northern Nigeria, Ahmadu Bello University Press, Zaria, Nigeria, 1977.

[10] G. Sorel, Reflections on Violence, Cambridge University Press, Cambridge, UK, 1969.

[11] Kaduna State Government, Projections: 1991 Census, 1991.

[12] T. Tamuno, Peace and Violence in Nigeria, Federal Government Press, Lagos, Nigeria, 1991.

[13] G. A. Almond and J. S. Coleman, The Politics of the Developing Areas, Princeton University Press, Princeton, NJ, USA, 1960.

[14] N. H. Galadimawa, "An analysis of urban planning challenges in Kaduna metropolis," Journal of the Nigerian Institute of Town Planners, vol. 22, no. 1, pp. 1-14, 2014.

[15] Department of Urban and Regional Planning and Kaduna Polytechnic, A Study of Partnerships in the Provision of Urban Public Services in Kaduna South Local Government Area, Kaduna State, Nigeria, Nigerian Urban Forum, 1999.

[16] B. Honig, Political Theory and Displacement of Politics, Cornell University Press, New York, NY, USA, 1993.

[17] O. Falae, "Unemployment in Nigeria," Nigerian Journal of Economic and Social Studies, vol. 13, pp. 59-74, 1971.

[18] U. Bar-Joseph and J. P. Hannah, "Intervention threats in short Arab-Israeli wars: an analysis of Soviet crisis behavior," The Journal of Strategic Studies, vol. 11, no. 4, pp. 437-467, 1988.

[19] Federal Office of Statistics, Dataset Records for Federal Office of Statistics (Nigeria), Federal Office of Statistics (Nigeria), 1995.

[20] B. Oni, "Graduate employment generation," in Nigeria in 2010, A. O. Philips and S. T. Titilola, Eds., N.I.S.E.R., Ibadan, Nigeria, 1997.

[21] K. G. Jiriko, Urban Master Planning Paradigm in Nigeria: What Future? Mba Prints \& Graphics, Kaduna, Nigeria, 2008.

[22] “The north: poverty disaster zone," The Market: Business, Policy and Economy Magazine, The North: Poverty Disaster Zone, vol. 3, no. 13, 2008.

[23] Federal Office of Statistics, Poverty Profile for Nigeria: 19861996, Federal Office of Statistics, Abuja, Nigeria, 1996.

[24] Vanguard, "Nigerian cities: away from heaven and hell," September 2000.

[25] BusinessDay, "Most Nigerians live in abject poverty," May 2002.

[26] The Guardian (Nigerian), "The Housing and Urban Development Ministry," February 2002. 
[27] T. Agbola and F. Kassim, "Conceptual and theoretical issues in housing," in Housing Development and Management: Book of Readings, T. Agbola, L. Egunjobi, and C. O. Olatubara, Eds., Department of Urban and Regional Planning, University of Ibadan, Ibadan, Nigeria, 2007.

[28] Federal Republic of Nigeria, National Report Prepared for Second U.N. Conference on Human Settlements (Habitat II: The City Summit), Istanbul, Turkey, 3-14 June, 1996.

[29] Urban Age, Summer. Exchanging International Experience, The Global City Magazine. Disaster city management, How cities can prepare for the worst, 37249, 1990.

[30] M. A. Yunana, A. T. Shat, N. H. Galadimawa, and M. T. Obasi, "Environmental implication of fuel wood consumption in Gora Area, Kaduna State, Nigeria," International Journal of Advanced Studies in Ecology, Development and Sustainability, vol. 2, no. 1, pp. 90-100, 2013.

[31] F. Fanon, The Wretched of the Earth, Penguin, Harmondsworth, UK, 2001, 1961 (French).

[32] E. Frazer and K. Hutchings, "On politics and violence: arendt contra fanon," Contemporary Political Theory, vol. 7, no. 1, pp. 90-108, 2008.

[33] R. I. Gofwen, Religious Conflicts in Northern Nigeria and Nation Building: The Throes of Two Decades, 1980-2000, Human Rights Monitor, Kaduna, Nigeria, 2004.

[34] E. A. Laso, Bringing People Together: Developing Peaceful Relations in the Divided City of Jos, Yakson Printing Press, Jos, Nigeria, 2014.

[35] The Guardian (Nigerian), Corruption in Nigeria, not just Boko Haram, is at the root of violence. Secrecy surrounding security matters and deeply entrenched corruption are failing communities across the country, 2014.

[36] R. J. Takaya, "The foundations of religious intolerance in Nigeria: backgrounds for understanding the maitatsine phenomenon," Bulletin of Ecumenical Theology, Jos University Press, vol. 2, no. 2, pp. 1-43, 1990.

[37] K. A. Balogun, "Religious intolerance as a cause of national disintegration," in Religion and National Unity, S. B. Mala, Ed., University Press PLC (UPPLC), Ibadan, Nigeria, 1988.

[38] Daily Trust (Newspapers, Nigeria), "How Crises Created 'Makka' and 'Jerusalem' in Kaduna", p. 4, February 2013.

[39] R. Obateru, "Planning the city to mitigate urban violence," in Urban Management and Urban Violence in Africa, I. O. Albert, J. Adisa, T. Agbola, and G. Herault, Eds., vol. I, IFRA, Ibadan, Nigeria, 1994. 


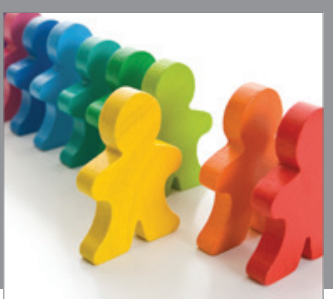

Autism

Research and Treatment
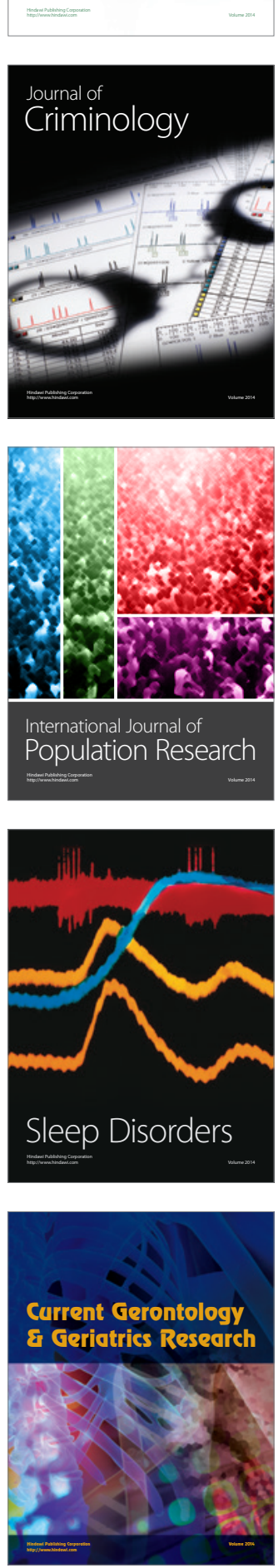

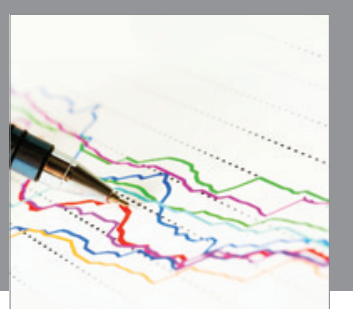

Economics

Research International
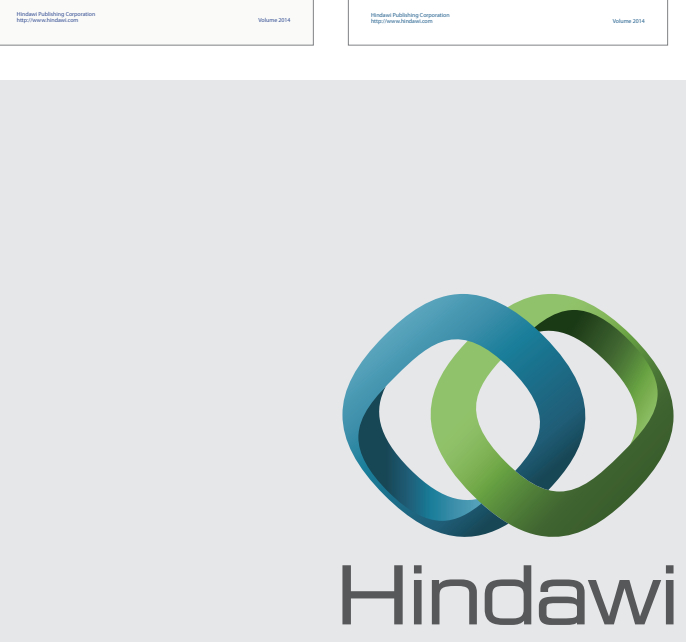

Submit your manuscripts at

https://www.hindawi.com
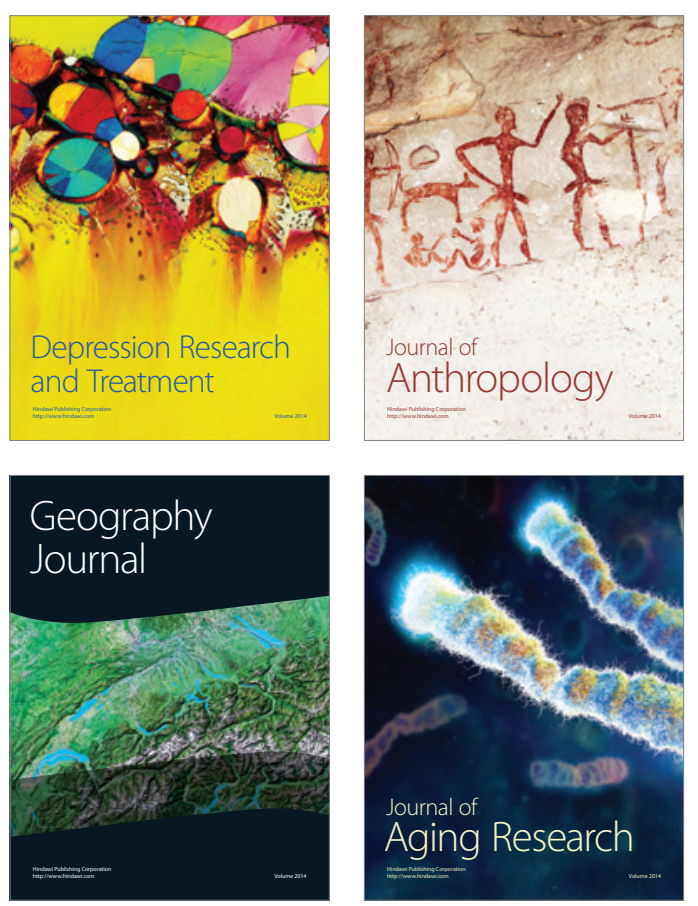
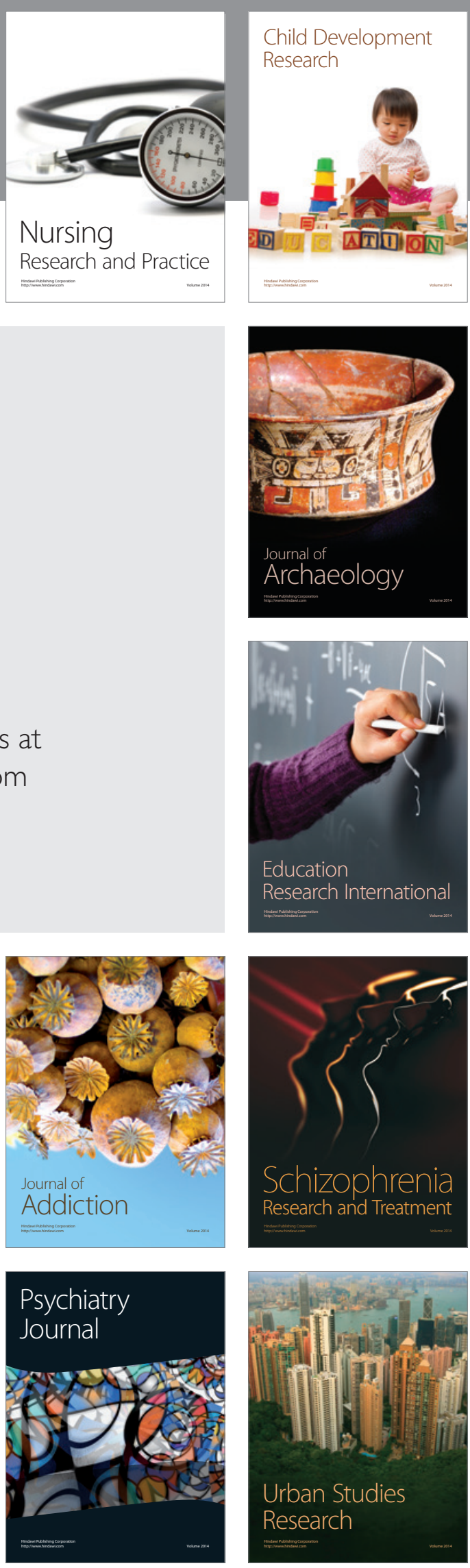